\title{
Making Differences: Cities, NGOs and the Cultural Politics of Development Discourse
}

\section{Carl O' Coill}

\author{
So geographers in Afric maps, \\ With savage pictures fill their gaps \\ And o'er uninhabitable downs \\ Place elephants for want of towns \\ Jonathan Swift $^{1}$
}

The field of development has produced a vast and multifarious body of knowledge on and about 'Third World cities'. The topic unites texts from disciplines as diverse as economics, political science, public administration, sociology and anthropology as well as planning and architecture. And it covers an extensive index of subject matter, anything from the cultural determinants of architectural form to the practicalities of urban waste management. Not surprisingly, academics outside the field often react with suspicion when confronted by the "irreducible untidiness" of development studies (Hulme \& Turner, 1990: 8). How can such an apparently disparate set of research interests constitute a coherent body of knowledge?

In the literature on cities and development, one finds very little to justify the general field of discourse. If the geography of the 'developing world' is defined at all it is usually defined unproblematically in terms of national economic statistics. Sometimes, the controversy surrounding words like 'Third World' or 'developing country' is acknowledged. Generally, however, definitional difficulties like this are quickly dismissed and research is justified by reference to the supposedly self-evident reality of the cities and countries specified within the investigation. Gilbert and Gugler maintain they merely use the category "Third World" as a "convenient shorthand" to 
denote the nations they list in Africa, Asia and Latin America (1992: 6-7). Similarly, Hardoy and Satterthwaite may criticise development's many "inaccurate generalizations and conceptions", but they do so not in order to reject its terminology but merely to validate their own claims to discover "what is actually happening in Third World cities" (1989: 9). Like all those who write in this area they presuppose that the discourse of development is capable of accurately representing real places.

Drawing upon evidence from the Kenyan context, this chapter argues that urban research in the field of development has never and cannot accurately describe the world. Development is not a tangible process or even a quantifiable goal (notwithstanding the wealth of positivist literature that assumes otherwise). It exists only as a domain of knowledge or 'discourse', a particular combination of signifying practices, vocabularies, narratives, images or ideas (Barnes and Duncan, 1992: 8). And, like all discourses, it bears the cultural imprint of its creators.

However, development academics' interpretations of non-Western cities have been shaped by understandings that are not only culturally specific, but are also necessarily political. From the very first writings in the field to the present, their research has been distinguished by a preoccupation with imaginary differences and hierarchies. The 'Third World city', ${ }^{2}$ as described in development discourse, is not an empirical reality. It is a Western invention, an imaginative construction that has helped to sustain a geometry of power and control that the West has exerted over its non-Western 'Others' in one form or another since the first days of colonialism. ${ }^{3}$ Consequently, this chapter concludes, development discourse is actually a barrier to meaningful communication between Western and non-Western people. 


\section{Building Hegemonies: The Social \\ Construction of the 'Third World City'}

In November 1991 an international workshop on cities and development was held at University College London. In addition to the usual gathering of academics who frequent such events, the workshop was attended by representatives from the World Bank the UNDP, GTZ and the former ODA. This event marked something of a shift in the field of development generally, that is, the revival of the city as a development imperative after nearly a decade of neglect and disparagement by these agencies. It was also one of the first times that official donors began to define a place for non-governmental organisations (NGOs) in the arena of urban poverty alleviation, enlarging further a form of 'charitable development' that has been expanding rapidly under official patronage since the early 1980s. In the published proceedings that followed the workshop, Nigel Harris noted the significance of this new urban agenda. He drew a vivid picture of the emerging landscape in "developing countries" and the enormity of the task ahead. After presenting the reader with a whole series of alarming statistics and predictions about population growth in 'Third World cities' he tells us,

The most striking feature of this [rapid process of urbanization] is the vast spread of squatter settlements and shanty towns, ill supplied, if at all with basic amenities. Rapid environmental deterioration, giant traffic jams, violence and crime, urban sprawl eating into the countryside, these are some of the most striking visible features of the growth of large cities in developing countries (1992: $x)$.

Most development academics are probably familiar with the image of disorder and 
crisis typified in Harris' representation of the generalised 'Third World city'. Devas and Rakodi have remarked that descriptions like this are something of a cliché in the field of urban development (1993: 1). They form the standard entry-point to nearly every undergraduate and postgraduate dissertation on the city in development studies. It almost seems as if the imagery itself is a mandatory learning requirement on the development curriculum. Even though Devas and Rakodi recognise the hackneyed language, they still follow the convention themselves, adopting a similar style of writing with all the usual statistics to emphasise their point. The researcher, they maintain, cannot escape the "basic facts" of mal-development in Third World cities.

Escobar and Crush (1995), two critics of development writing from a post-structuralist position, maintain that images like these are prevalent in development generally and can be traced throughout the history of the discourse. They offer a very different explanation for their prevalence. Representations of disorder, they maintain, were the stock in trade of the European colonist in the eighteenth and nineteenth century. They signified not so much real disorder as difference, or the absence of an imagined order that was peculiarly white and Western. Then, as now, the function of such representations is to discipline as well as to describe. Historically they have provided a justification for outside intervention in the territories of other people and, ultimately, for the re-ordering of non-Western societies in the image and interests of Western power.

Understandably, some people may find this argument difficult to accept. How can anyone equate our own field of study, urban research, with racist colonial prejudices when all our efforts are so clearly directed towards improving the welfare of urban 
populations? In fact urban development is an unusual case, and one that illustrates particularly well both the racist foundations of development discourse and its disciplinary functions. An examination of changes in representations of African cities in the Western academy and the media can tell us a lot about the place of race in development discourse primarily because most of Africa's cities were built by white Europeans and, at one time, inhabited by them.

Throughout the colonial period the disorder Europeans perceived in other peoples' territories was generally explained in terms of a hierarchy of race. Different 'races' were characterised by differing traits and capacities. Most often the social hierarchy that Europeans sought to impose found expression in a metaphor of time. At first, racial differences were seen as given in nature. 'Races' were mapped out along an evolutionary time scale reflecting differing degrees of biological advancement. Later, cultural development was used as the marker and different societies were positioned in anthropological time in accordance with the degree to which they were thought to lack civilization - "the general standards for which the West took to be its own values universalised" (Goldberg, 1993: 4). According to Goldberg,

Those of the East were acknowledged to have civilisation, language, and culture. But, generically, the East was a place of violence and lascivious sensuality, the rape of which was thus invited literally as much as it was metaphorically. Africa to the South, by contrast, was the Old World of pre-history: supposedly lacking language and culture, the Negro was increasingly taken to occupy a rung apart on the ladder of being, a rung that as the eighteenth century progressed was thought to pre-date humankind (1993: 29).

These differences and hierarchies carried over into understandings of Africans' and Asians' engagement with urban life. In the British colonial mentality, the presence of 
an indigenous urban culture in Asia was itself taken as a sign of civilisation. It was one of the traits that placed the Oriental 'race' above the African, whose urban history was generally not recognised. In consequence, urbanised Asians were more easily accepted within the colonial order. In colonial Nairobi Asians may have been associated with disease and crime and segregated from whites, but they were acknowledged as permanent residents of the city and afforded a certain degree of autonomy on that basis. ${ }^{4}$ Urbanised Africans on the other hand, were perceived as an aberration of nature and culture. In British eyes, their proper place was closer to nature in the rural, village society. For most of the colonial period, despite the fact that Africans made up the largest segment of Nairobi's population, they were designated merely temporary residents of the city and were subject to many more controls and restrictions than Asians. According to Lord Luggard, the author of the colonial policy of indirect rule, the urbanised African was a socially "displaced person" and, on this basis, should be considered something of a degenerate (Werlin, 1974: 48).

Not surprisingly perhaps, the image British colonists had of Africa as an uncivilised and chaotic terrain was rarely applied to the African cities they built for their own purposes. If one studies representations of Nairobi in the British press and in popular magazines from the 1940s and 50s, prior to Kenya's independence, the picture one finds is quite the opposite of the 'Third World city' as commonly perceived today. At this time Nairobi was more usually seen as a place of order and prosperity. In 1950 it was the first town in the British Empire to receive a Royal Charter designating it a city. The article that appeared in The Times marking the event stressed the many similarities between Nairobi and ordinary English cities. Most British people who visit Nairobi for the first time, its author claimed, "are surprised by its size and its 
modernity", its "pleasant, red-tiled, English-style homes", "golf courses", "green lawns and tree-shaded gardens" (1950: 7). The article is entitled "From Swamp to City within the Span of a Lifetime'. In the founding of Nairobi, it celebrates the imposition of a new and distinctly English order upon a pre-existing African landscape that was represented as both chaotic and desolate.

Now, let us stop for a moment and jump forward to 1964, one year after Kenya achieved its independence. In that year Charles Abrams published his book, Man's Struggle for Shelter in an Urbanising World, one of the seminal sources on 'Third World' urban development. After providing the reader with a whole series of statistics and dire predictions about population growth and urban-rural migration in the "developing world" Abrams gives us the following account,

With the surge of population from the rural lands to the cities, a new type of conquest is manifesting itself in the developing world. Its form is squatting... Little one roomed shacks built of adobe and scrap are cropping up in Medellín, Barranquilla, and Cali, Colombia, and in fact throughout Latin America. The colonies lack paved streets, a sewage system, and a water supply. Havana has a profusion of rude huts without sanitary facilities. In Algiers, tin-can towns, or bidonvilles, stand just five minutes away from the centre of the city in almost any direction... Around the edges of Johannesburg, South Africa, sprawl squatter colonies that are a chaos of shacks and hovels pieced together by the homeless and destitute. In India's larger cities, squatters can be found hanging on to their precious hovels in old forts or wherever they can find a foothold (1964: 13-14).

What we have here is an early image of the 'Third World city' as a generalised landscape. Although Abrams' description is now well over thirty years old, remarkably, it is very similar in form to the description of the 'Third World city' Nigel Harris provides today. For me, however, what is most striking about this image is how completely different it is from the picture The Times portrayed of Nairobi in the 1950s. 
Why is this? Notwithstanding Abrams' account of squatting as "a new type of conquest", most colonial cities were not suddenly swamped with shantytowns after independence. The shantytowns were always there. The depiction of Nairobi as ordered and prosperous in the British press of the 1950s makes sense only if one accepts that the shantytowns were not part of the urban landscape, that Nairobi was not a black African city but a white European city.

So what is the point being made here? Of course, after independence Nairobi was a black African city. That said, it would be wrong to suggest that one could account for the contrary descriptions of the colonial and post-colonial city purely by pointing to the change in colour. What these examples are intended to illustrate is the disciplinary function of discourse, the way that representations of disorder are used to signify cultural difference and to justify the control of 'Others'. In almost all of the articles written about Nairobi in the British press during the colonial period, the greatest disorder was understood to lie not within the city, but outside it in the form of the black African masses who threatened to return this pristine urban landscape to its savage beginnings. As we saw, however, Nairobi's boundaries, who was inside and who was outside the city, were not defined in spatial terms but in terms of cultural differences. The degree to which one was a resident of Nairobi depended not on one's physical distance from the centre of the city, but on one's cultural distance from the centre of civilisation, the West. For the British, Nairobi to all intents and purposes did not have a black African population because Nairobi was a Western city. The line of difference drawn was not purely black/white it was Western/non-Western or, on a more elemental level, other/same, them/us. 
So why did this image of the colonial city change so suddenly after independence? Firstly, when we look at Abrams' description, it is important to note that Abrams himself was not British; he was a naturalized American. In fact, most of the authors writing about urban issues in the so-called 'developing world' in the 1950s and early 60s were American. Hoselitz (1953), Friedmann (1965) and Mangin (1967) were all Americans. Cognisant of this, it is much easier to understand why the image presented was different. Americans were not accustomed to the subtle distinctions and gradations the British had drawn between black and white, Western and non-Western, either in terms of places or categories of people. For Abrams the line between 'them' and 'us' was more simply defined; there were no white American cities in Africa or Asia. The whole of the post-colonial world was seen as a generalised field of difference. The British could not participate fully in this peculiarly American vision until they had experienced what Stewart Hall calls, "a kind of historical amnesia" (Hall, cited in Hesse, 1997: 92). This was a period that instituted the "forgetting of Empire" and established the notion that "race is nothing intrinsically to do with the condition of Britain" (Hesse, 1997: 92). ${ }^{5}$

But of course colonial cites were portrayed differently after independence, one might argue; we all recognise now that life under colonialism was highly unjust, but nobody would expect the British colonial regime to acknowledge this fact by celebrating the existence of shantytowns in the midst of Nairobi, a city they had created. Surely Abrams and others like him were merely demolishing this pretence and pointing to the reality of the situation on the ground? No, in the urban disorder they identified, Abrams and others like him were more concerned with marking imaginary differences and hierarchies than describing any reality. How do we know this? We know this 
because the discourse of development, the discourse they created, is just as blind to the possibility of any form of disorder in Western cities as was the racist colonial discourse that preceded it.

Post-structuralist theorists maintain that words and images are invariably inhabited by "traces" or footprints of other absent images or words, that the meanings ascribed to particular objects, groups of people or places depend entirely on their relation to, or difference from other people and places (Sarup, 1993: 38). The specialism of urban development has always relied on the assumption that the West is diametrically opposed in every feature to the so-called 'developing world'. On this basis, the generalised 'Third World city' and its inhabitants are usually described only in terms of what they are not. They are chaotic not ordered, traditional not modern, corrupt not honest, irrational not rational, lacking in all of those things the West presumes itself to be. The Americans, in constructing development discourse, maintained an essentially arbitrary cultural distinction, Western/non-Western, in their descriptions of the post-colonial cities they encountered. They merely changed the signifiers of difference from racial traits to economic characteristics. ${ }^{6}$

Once again, evidence of this is provided by the many absences in the discourse, its geographical blind spots. In the past, capitalist European countries like Ireland, Spain, Portugal and Greece, as well as communist countries like Albania, Romania and Yugoslavia, have all fallen below the income level the World Bank set for membership of the developed world. But just as Nairobi was excluded from colonial depictions of Africa as a disordered terrain, these places were rarely, if ever, included in discussions of the developing world. To their credit, Gilbert and Gugler highlight this 
anomaly in their book, Cities, Poverty and Development (1992). However, they still insisted upon following the convention themselves.

The blind spots are not simply confined to national characteristics. The unspoken assumption that underpins most representations of the 'Third World city' in development discourse, that Western cities are not like cites in Africa, Asia or Latin America, has never been true. As Trinh T Minh-ha points out, there have always been Third Worlds in the First World just as there have always been First Worlds in the Third World (cited in Featherstone, 1995).

This was certainly the case in the decade following the war, although it is not apparent in Abrams' work. Abrams lists a whole series of former colonial cities where squatting emerged as response to housing shortages. He compares this situation with the European experience of squatting. But he locates this experience in Europe's distant past, pointing to practices of land use prior to the Acts of Enclosure in Britain in the eighteenth century. In fact, squatting was rife in Europe after the Second World War. In Britain in the 1940s, tens of thousands of homeless people were squatting in disused housing, in army camps, in vacant office blocks and in the empty mansions of the wealthy (Friend, 1980: 110-18). In France population growth and rural-urban migration on a scale comparable to post-colonial countries exacerbated urban housing shortages. Several hundred thousand people were still living in makeshift shantytowns on the outskirts of Paris and other major cities as late as the mid-1950s (Power, 1993: 40).

The fact that Abrams' did not see these shantytowns cannot simply be dismissed as 
an accidental oversight. This omission reflects the endurance of a system of representation rather than the lack of vision of a single author. When Abrams chose to locate urban disorder in the West in its distant past he was relying upon a long established discourse. He was stretching difference out along a linear time scale, drawing upon a metaphor that was similar in outline, if not in detail, to the racist metaphor of hierarchy used by the British colonial regime.

Now, if we shift our attention to the present and look once again at Harris' account of the 'Third World city' we can identify precisely the same regularities. Harris maintains that the "most striking visible features of the growth of large cities in developing countries" are the "spread of squatter settlements and shanty towns... rapid environmental deterioration, giant traffic jams, violence and crime, and urban sprawl" (1992: x). Now, by no stretch of the imagination could one say that Africa, Asia and Latin America have a monopoly on environmental decay, traffic jams, crime or urban sprawl. To my mind all but the first of these are equally characteristics of the growth of large cities in the West. Americans, for example, produce more refuse and more greenhouse gasses than anyone else on the planet. Greater Los Angeles is the archetype of urban sprawl. It is spread out over a sixty-mile wide circle and, some argue, consists not of one, but five distinct cities absorbed within a continuous urban conglomeration. As for traffic jams and crime, notwithstanding the fact that the number of vehicles on US roads has doubled since 1970, more people are killed by gunfire in Los Angeles than by traffic accidents (Beder, 1997: 233; Anderson, 1996: 359-60; Soja, 1996: 433-38).

Harris is setting up the same hierarchy we identified with Abrams. It is present in the 
implied polarity between Western and 'Third World cities', the unspoken assumption that the West is free of traffic jams. Later, it is stated more explicitly when he draws a comparison between nineteenth century attitudes to urbanization in Britain and what he claims are entrenched anti-urban attitudes amongst governments in "developing countries" (1992: x-xiii). Harris' comments in this regard are especially ironic considering the agencies he was addressing, the World Bank in particular, spent nearly two decades bullying post-colonial governments into prioritising agricultural development and abandoning the social welfare programmes and import substituting industrialisation strategies that largely sustained urban populations.

It would be easier to tolerate the persistence of fictional differences and hierarchies in development discourse if such wrong-headedness could simply be put down to unthinking habit. However, the image development presents of the 'Third World city' cannot be seen as purely accidental. Western representations of 'Other' people and places have almost always coincided with and reinforced Western interests. In colonial Nairobi the racist stereotyping of urban Africans as degenerate and uncivilised served a definite cultural-political purpose. It enabled Nairobi's Europeans to reinforce their own identities as a 'decent', 'upstanding', urbanised gentility while simultaneously justifying the differential treatment they apportioned to Africans. The restricted access that Africans were afforded to the basic necessities of urban life, the frequent appropriations of land and property and the arbitrary expulsions, detentions and even killings, could more easily be accepted as legitimate so long as it was believed that Africans were 'not like us'. Since the end of the colonial period, it is the discourse of development primarily that has served to legitimate this differential treatment. 
This is most evident when one contrasts America's relations with Europe after the war with its treatment of post-colonial countries. Post-Marxists refer to the arrangement that emerged between America and other Western nations after the war as "Fordism" (Harvey, 1990; Lipietz, 1992). Theorists in international relations refer to it as the "post-war hegemonic order" (Gill, 1993 \& 1992; Cox, 1993). After the war America could have reduced Europe to the level of an underdeveloped economy by exposing its industries to relentless competition in free trade. Instead it chose to finance the reconstruction of its competitors' industries and to tolerate the protectionist bias Europe employed in international trade. According to Lipietz the restraint America exercised in international trade allowed European governments the space to negotiate the social contract that ultimately united mass production with mass consumption. Increases in productivity in industry could only be matched by higher levels of demand when state regulation compelled the business community to pay higher wages to their workers, increase levels of employment and pay taxes at a rate sufficient to support social welfare programmes. Unbridled international competition could easily have undermined this system of regulation by encouraging industrialists to engage in continuous cost cutting. The post-war order gave rise to what many have since called the "golden age" of capitalism, a period of unparalleled economic growth and stability that raised living standards for millions of ordinary people throughout the Western world.

Outside the West, however, American magnanimity did not extend very far. Post-colonial nations were never fully included within these arrangements. While the American vision of 'development' appeared to offer a more inclusive path to 'progress' than had previously been the case, in fact the discourse was little more than a 
superficial reformulation of racist colonial prejudices. It provided a means of subverting popular aspirations for radical change in the context of anti-colonial struggles while legitimating the continued marginalisation of non-Western peoples. After independence development discourse worked to undermine indigenous customs of ownership as well as an expanding communist ideology, both of which threatened to obstruct the expansion of Euro-American capitalism in the former colonies. And it achieved all this while providing very little in the way of tangible benefits to non-Western people. There was no Marshall plan for Africa. The limited assistance post-colonial countries received in development aid was usually tied more directly to short-term Western interests. As a portent of things to come, Kenya began its independence in the 1960s owing a debt of 29 million pounds, a loan that the World bank arranged to ensure that departing British colonists would be paid for returning part of the land they had originally stolen from the indigenous population (Leys, 1975: 74).

In the decades after the war, in keeping with national Fordist arrangements, urban development was seen almost entirely in terms of state planning within a national or local context. Today city managers compete globally to attract inward investment and the business community rather than the state dictates the terms under which development occurs. The explanation most often given for the emergence of this 'market-friendly' approach to urban development is government failure. Government management failed in the 1970s, many have asserted, because state bureaucracies were inherently inefficient. Post-Marxists argue that the failure was wider than this; it involved the gradual collapse of the post-war compromise in the West and the breakdown of the entire system of economic and social regulation upon which it was 
built. The post-war order they maintain, is currently being replaced by an even more exclusionary system of "flexible accumulation" (Harvey, 1990: 121-89), or what in common parlance is often referred to as the 'neo-liberal' economy. ${ }^{7}$ How did this happen? According to Castells, an important faction of the business community was and is willing to do whatever is necessary to re-instate the pre-war conditions of low wages, low welfare spending, low corporate taxes, minimal regulations and weak unions consistent with high profit margins (1991: 231). ${ }^{8}$ From the 1980s onwards, rather than resisting these demands, Western governments chose to encourage them.

As long as America and its partners in the West sustained the post-war social contract, one could argue that the differences established within development discourse made some sense. Poverty in the West simply did not occur on anything like the scale of post-colonial countries. This is no longer the case. The collapse of the post-war order has brought about a huge increase in levels of poverty and inequality across the entire globe. The expression 'there are Third Worlds in the First World' is more true today than it has ever been in the past. There are now more than 37 million people without work in OECD countries (UNDP, 1998: 27; 1997: 3). Over 42 thousand people are officially classed as homeless in London (Shelter, 2001: 1). ${ }^{9}$ Recent estimates place the number of homeless in Los Angeles County at more than 200 thousand (Wolch, 1996: 390). Nigel Harris' may be right when he implies that shantytowns are found exclusively in the "developing world". However, the only reason there are no shantytowns in Los Angeles is because any attempt by the homeless to build makeshift shelters in the city is usually met with the kind of immediate and brutal repression students of development more commonly associate with 'Third World' regimes (see for example, Davis, 1992). 
The support governments everywhere have shown for the work of NGOs in recent years and for voluntarism in public life generally, must be seen in the context of the ascendancy of neo-liberal doctrine and the growth in inequality worldwide. The trend towards voluntarism does not reflect a rising interest in popular democracy as is commonly presumed, but a deeply cynical abandonment of post-war concerns with social welfare and social justice.

Africa's cites would not be in the deplorable condition they are today if official development agencies had shown as much concern for the welfare needs of urban populations in the 1980s as they did in previous decades. Notwithstanding its failings, Kenya's state-led economy of the 1960s and 70s did at least sustain a narrow, urban middle-class and help to finance a social infrastructure that, while not comparable to Fordist conditions in the West, nevertheless served a wider urban population. Since the 1980s the imposition of neo-liberal policies under structural adjustment programmes has led to chronic disinvestment, urban-industrial decline and deepening poverty not only in Kenya's cities, but throughout Africa. ${ }^{10}$ Charitable development will not rectify this situation.

In Nairobi those few NGOs that are active in urban areas work with hundreds of people or at best a few thousand when more than half a million live in shanty towns with little or no access to adequate shelter and increasingly insufficient means to pay for basic services like health and education. ${ }^{11}$ However, charitable development is an inadequate response to urban poverty not merely because the scale of assistance provided by NGOs is almost negligible. ${ }^{12}$ It is inadequate because voluntary 
organisations are incapable of providing the kind of public control that is necessary to protect people from exclusionary market relationships, whether in international trade or in urban housing markets. Nor can they perform the redistributive functions the state must undertake in order to establish an equitable and effective system of social welfare. If one asks why NGOs did not figure prominently on the development scene in the 1960 s and 70 s, the most likely answer is because, at the time, this fact was widely appreciated. ${ }^{13}$

Once again there are many similarities between shifting attitudes in the West and in post-colonial countries. In Britain, official attitudes to charity altered considerably in the 1980 s to the extent that voluntary sector provision became accepted as a substitute for state welfare rather than merely a complement. In 1979 government grants to voluntary sector organisations as a whole totalled £93 million, by 1986 this figure had increased to $£ 300$ million (Ware, 1989: 2). By the end of the decade, charity was being used to fund large-scale provision of social housing as well as health provision, both capital costs, like the building of new hospitals, as well as the routine costs of patient care (Hanna, 1991: 23). It should be remembered that the British National Health Service was established in the 1940s to overturn the inadequate and inequitable system of care provided by hospitals dependent on charitable funding. More recently, America's new president, the staunchly neo-liberal Bush, has made the substitution of state welfare with voluntary sector provision a central plank of his social welfare strategy.

In the context of welfare retrenchment and growing inequality worldwide, development discourse often claims to seek a global solidarity. However, it continues to define the 
world in two opposing halves telling each half in a different way that their problems are separate. Advocates of development transform trade, environmental and labour rights into "Southern" or "North-South issues" and make appeals to Western charity to fill the 'others' lack. These narratives feed into and reinforce other discourses of Western difference and identity in popular culture, the exotic in tourist representations of the post-colonial world, the constant media images of chaos and anarchy in Africa, the only reports that ever seem to reach Western television screens. They all say the same thing, that their places are 'Other' than ours, that their problems are not our own.

\section{Conclusion}

The argument often made in support of multiculturalism, that all cultural differences should be respected equally, is naïve. It does not take account of the power dynamics of culture, the way that cultural differences are constructed and propagated to further narrow social interests. Real differences do exist. But they can also be transcended in specific contexts to create relations of affinity and solidarity. Where we chose to draw the line that separates 'us' from 'them' is largely a political decision. Unfortunately, researchers in the field of urban development have always been far more concerned with promoting the latest strategies for development intervention than questioning the interests upon which development practice is based. If we truly are concerned with the growth of poverty in the world today we need to ask ourselves how effective is it politically for us to perpetuate the fiction that the 'First World' and the 'Third World' are two different places? 
To conclude, one cannot 'communicate for development' because, as stated earlier, development is not a tangible process or goal, but a discourse. However, more and more researchers are also beginning to recognise that one cannot communicate effectively 'with' or 'through' development because the discourse itself is ultimately concerned with power and control. It does not provide a basis for a dialogue between Western and non-Western people on equal terms. And it discourages both parties from recognizing the common problems and common interests that span the West/non-West divide, in particular the threat neo-liberal ideology presents to social welfare and social justice at a global level. For growing numbers of development sceptics, the most significant line of difference to draw today is not the line separating the West from 'the Rest', but the line separating apologists for the prevailing doctrine of neo-liberalism from people everywhere who seek its downfall. To paraphrase Arturo Escobar, we do not need any more alternatives of development, what we need now are alternatives to development (1995: 215).

1. This quotation is from Swift's, On Poetry: A Rhapsody (1733) and was cited in Anne McClintock (1994: 27).

2. The term 'Third World' itself, it is true to say, was not simply a western construction but was part of the vocabulary of the non-aligned movement. However, as Harris points out, the expression no longer signifies the non-aligned countries it was originally intended to describe but has gradually come to stand for all "developing countries" (1986: 7). I use the term in a wider sense to refer to a discourse about non-Western cities with its origins in Western modernity.

3. "The West" here is not meant to denote an area defined by lines of latitude and longitude on a map. As Stewart Hall points out, "'the West' is a historical not a geographical construct" (Hall, 1994, 277). Michael Keith and Steve Pile refer to the term as a "linguistic condensation of the globally powerful" (1993: 22). It delineates a cultural space occupied by a particular form of rationality or modernity, a collection of principles for organising people in time and space rather than an area on a geographical map. And, it is defined as much by how it represents its "Others", the Non-West or, as Hall puts it, "the Rest", as by how it sees itself. In this sense of the word Japan, although east of Europe, could be understood as similarly "Western".

4. For example, while Asians were allowed some direct representation on Nairobi's Municipal Council, Africans were not.

5. It is interesting to note that John Turner, one of the early and more celebrated British authors writing about cities in 'developing countries', lived in Peru in the 1950s and spent the 1960s in North America working at the same research institute as Abrams and Friedmann.

6. The position I am taking here, some will say, is nothing new. In the mid-1980s Nigel Harris himself was arguing that the 'Third World' had come to an end (1986). The distinction traditionally drawn 
between developed and developing regions, the 'First' and the 'Third World', he claimed, was no longer valid. "Newly industrialising countries" like Korea, Malaysia and Singapore had grown so much economically in recent decades, he maintained, that they now have more in common with the West than they do with most other developing countries. My argument, however, is that the distinction has always been arbitrary, that the economic changes Harris identifies are not nearly so significant as he thinks because development discourse has always been far more concerned with marking cultural difference than charting economic statistics.

7. The term neo-liberalism is most widely used in Latin America. It is a term more often applied in criticism than in praise having been adopted to describe the economic policies imposed in the region after the international banking crisis of the early 1980s, or the so called 'third world debt crisis'. Broadly speaking, neo-liberal doctrine is distinguished by the primacy it affords the role of 'the market' in human affairs and the laissez-faire approach to government it advocates. It is so called because it is generally seen as a revival or variant of the economic liberalism that prevailed in the 19th and early 20th century. As an ideology, it stands in opposition to Keynesianism and the post-war consensus of the welfare state, the system that supplanted the nineteenth century liberal order. Its declared aim is 'efficiency', welfare maximization through market competition. State intervention in the marketplace is conceived as stifling of competition, by definition inefficient. Thus, the liberalism espoused is always an economic liberalism, the freeing of business from state control. Although neo-liberalism is generally associated with the right-wing governments of Margaret Thatcher and Ronald Regan, neo-liberal policies were implemented before this in the 1970s, by the Pinochet regime in Chile, and by the Labour governments of Wilson and Callaghan in Britain. The policies neo-liberalism encompasses include the privatisation of public enterprises, reductions in government spending, deregulation of domestic markets, removal of barriers to international trade and investment, the promotion of 'export-led growth', and monetarist policies directed toward the control of inflation. Today, the neo-liberal outlook is taken for granted in countries all over the world and is embraced as much by traditionally left-of-centre, social-democratic governments as by the right.

8. The neo-liberal agenda is extremely short sighted. As Lipietz and Harvey point out, in the long run, the business community must employ sufficient numbers of people and increase wages sufficiently to allow workers to become consumers of the goods they produce. Cutting wage costs while pushing for greater levels of productivity makes no sense. The overproduction that inevitably results creates deflationary pressures that can eventually lead to recession or even depression. In other words, the neo-liberal agenda is not even in the long-term interests of capitalists themselves.

9. It is notoriously difficult to arrive at an accurate estimate of the number of people sleeping rough in London on any given night. The figure given here for the number of homeless in the city was compiled by the British voluntary organisation Shelter from Local Authority and DETR statistics. It includes people in temporary accommodation as well as people living on the streets. However, as Shelter points out, these statistics show only the number of households who approach local authorities for help and are found to be homeless. Under the Housing Act 1996 councils have a duty to house 'priority need' homeless households in temporary accommodation for a period of two years. Thus, the figure of 42 thousand homeless does not include people for whom local authorities have no responsibility to provide accommodation and who do seek or get help from their council. The majority of single people or childless couples are included in this category.

10. By insisting on the elimination of trade barriers official development agencies removed one of the few bargaining chips that post-colonial governments held in the competition for inward investment. Once these trade barriers had been removed multinational corporations no longer needed locally based production centres to supply Africa's domestic markets with goods. The African market could be supplied from America, Britain, Mexico or China, or wherever investors were offered the best deal in terms of low production costs, minimal regulation and high value incentives. Encumbered by debt, African governments could not and still cannot compete with the scale of business inducements offered by countries in the West and in South East Asia. Between 1989 and 1994 the number of British manufacturing companies with equity holdings in Anglophone Africa dropped by one third. In the five years between 1988 and 1993 an annual investment from France of 1 billion dollars turned into a net outflow of 800 million dollars (Ayittey, 1998). Total Inflows of foreign direct investment in Kenya amounted to 39 million between 1986 and 1990. These inflows dropped to a total of just $\$ 8.9$ million in the 4 years from 1990 to 1994 (Ikiara, 1996). . 
11.Rising costs of living have seriously eroded peoples' incomes in Kenya's urban areas. Real wages in Nairobi fell by $45 \%$ between 1982 and 1994, and by $55 \%$ in urban areas as a whole (Ikara \& Ndung'u, 1999: 99).

12.In fact, the scale of assistance provided by NGOs in general is negligible. If we add up all the money Western NGOs spent in 'developing countries' in 1995, 6.7 billion dollars, it amounts to less than one ninth of the British government's annual budget for its National Health Service. But more tellingly, the figure is thirty six times less than the 246 billion dollars 'developing countries' spent on debt repayments to the West in the same year [this figure was compiled from statistics cited in the Human development Report 1998, (UNDP, 1998)].

13.In relation to land, for example, the 1976 Habitat recommendations state: "Private land ownership is... a principal instrument of accumulation and concentration of wealth and therefore contributes to social injustice; if unchecked it may become a major obstacle in the planning and implementation of development schemes ... [its] management should be subject to public surveillance or control in the interest of the nation" (Habitat, in Hardoy and Satterthwaite, 1981, 227). Levels of inequality in distribution of property have worsened significantly since the 1970s. Despite this fact, this kind of public control over land ownership is rarely recommended today. 


\section{Bibliography}

Abrams, Charles (1964) Man's Struggle for Shelter in an Urbanizing World, The MIT Press, Cambridge Mass.

Anderson, Susan (1996) 'A City Called Heaven: Black Enchantment and Despair in Los Angeles', in Allen Scott \& Edward Soja, eds., The City: Los Angeles and Urban Theory at the End of the Century, University of California Press, London

Ayittey, George B. N. (1998) 'Africa in Chaos', extract from book by same author in, New York Times on the Web [online archive], New York Times. Available from, http:Ilwww.nytimes.com [Accessed 13\10198].

Barnes, Trevor J. and James S. Duncan, eds. (1992) Writing Worlds: Discourse, Text and Metaphor in the Representation of Landscape, Routledge, London.

Beder, Sharon (1997) Global Spin: the Corporate Assault on Environmentalism, Books Ltd, Dartington Green.

Castells, Manuel (1991) The Informational City: Information Technology, Economic Restructuring and the Urban-Regional Process, Basil Blackwell, Oxford:.

Cox, Robert W. (1993) 'Gramsci, Hegemony and International Relations: an Essay in Method', in Stephen Gill, ed., Gramsci and Historical Materialism and International Relations, Cambridge University Press, Cambridge

Crush, Jonathan, ed. (1995) Power of Development, Routledge, London.

Davis, Mike (1992) 'Fortress Los Angeles: the Militarization of Urban Space', in Michael Sorkin, ed., Variations on a Theme Park: the New American City and the End of Public Space, Noonday Press, New York.

Devas, Nick \& Carole Rakodi (1993) 'The Urban Challenge', in Devas and Rakodi, eds., Managing Fast Growing Cities: New Approaches to Urban Planning and Management in the Developing World, Longman, Harlow.

Escobar, Arturo (1995) 'Imagining a Post-Development Era', in Crush, ed., Power of Development, Routledge, London.

Featherstone, Mike (1995) Undoing Culture: Globalization, Postmodernism and Identity, Sage Publications, London.

Friedmann, John (1965) Regional Development Policy: A Case Study of Venezuela, The MIT Press, Cambridge, Mass.

Friend, Andrew (1980) 'The Post-War Squatters', in Nick Anning, et, al., eds., Squatting: the Real Story, Bayleaf Books, London.

Gilbert, Alan \& Joseph Gugler (1992) Cities Poverty and Development: Urbanization in the Third World, Oxford University Press, Oxford.

Gill, Stephen (1993) 'Gramsci and Global Politics: Towards a Post-Hegemonic Research Agenda', in Gill, op cit.

Gill, Stephen (1992) 'Economic Globalization and the Internationalization of Authority: Limits and Contradictions', Geoforum. 23 (3): 269-283.

Goldberg, David Theo (1993) Racist Culture: Philosophy and the Politics of Meaning, Blackwell, Oxford.

Hall, Stewart (1994) 'The West and the Rest: Discourse and Power', in Stewart Hall \& Bram Gieben, eds., Formations of Modernity, Polity Press, Cambridge.

Hanna, Lynn (1991) 'Sweet Charity Swings Low', The Guardian, (Dec $\left.18^{\text {th }}\right): 23$.

Hardoy, Jorge E. \& David Satterthwaite (1989) Squatter Citizen: Life in the Urban Third World, Earthscan, London.

Hardoy, Jorge E. \& David Satterthwaite (1981) Shelter, Need and Response, Housing, Land and Settlement Policies in Seventeen Third World Nations, John Wiley and Sons, Chichester.

Harris, Nigel, ed. (1992) Cities in the 1990s: the Challenge for Developing Countries, UCL Press, London.

Harris, Nigel, ed. (1986) The End of the Third World: Newly Industrializing Countries and the End of an Ideology, Penguin Books, London.

Harvey, David (1990) The Condition of Postmodernity: an Enquiry into the Origins of Cultural Change, Blackwell, Oxford.

Hesse, Barnor (1997) 'White Governmentality: Urbanism, Nationalism, Racism', in Sallie Westwood \& John Williams, eds., Imagining Cities, Routledge, London.

Hoselitz, Bert F. (1953) 'The Role of Cities in Developing Countries', Journal of Political Economy (61): 195-208. 
Hulme, David \& Mark Turner (1990) Sociology and Development: Theories Policies and Practices, Harvester Wheatsheaf, London

Ikara, Gerrishon (1996) 'The European Union-ACP Relationship: The Case of Eastern Africa', [online archive]. Euroforic. Available from: http://www.oneworld.org/_euforic/fes/4gb_iki.htm [Accessed 8|3199].

Ikara, Gerrishon and Njuguna Ndung'u (1999) 'Kenya', in Willem van der Geest and Rolph ven der Hoeven, eds., Adjustment, Employment and Missing Institutions in Africa: The Experience in Eastern and Southern Africa, ILO, Geneva.

Keith, Michael \& Stephen Pile (1993) 'The Place of Politics', in Keith \& Pile, eds., Place and the Politics of Identity, Routledge, London.

Leys, Colin (1975) Underdevelopment in Kenya: the Political Economy of Neo-colonialism, 1964-1971, Heinemann, London.

Lipietz, Alain (1992) Towards a New Economic Order: Postfordism, Ecology and Democracy, Blackwell, Oxford.

Mangin, William (1967) 'Latin American Squatter Settlements: a Problem and a Solution', Latin American Research Review, . (2) 65-98.

McClintock, Anne (1994) Imperial Leather: Race, Gender and Sexuality in the Colonial Contest, Routledge, London.

Power, Anne (1993) From Hovels to High Rise: State Housing in Europe Since 1850. Routledge, London.

Sarap, Madan (1993) An Introductory Guide to Post-Structuralism and Postmodernism, Second Edition, Harvester Wheatsheaf, New York,.

Shelter (2001) 'Regional Statistics Briefing: London', unpublished statistical bulletin. Shelter, London.

Soja, Edward W. (1996) 'Los Angeles, 1965-1992: from Crisis-Generated Restructuring to Restructuring-Generated Crisis', in Scott \& Soja, eds., The City: Los Angeles and Urban Theory at the End of the Century, University of California Press, London.

The Times (1950) 'Royal Charter for Nairobi: From Swamp to City Within the Span of a Lifetime', $\left(30^{\text {th }}\right.$ March): 7.

United Nations Development Programme (1998) Human Development Report 1998, Oxford University Press, Oxford.

United Nations Development Programme (1997) Human Development Report 1997, Oxford University Press, Oxford.

Ware, Alan, ed. (1989) Charities and Government, Manchester University Press, Manchester.

Werlin, Herbert H. (1974) Governing an African City: a Study of Nairobi, Africana Publishing Company, London.

Wolch, Jennifer (1996) 'From Global to Local: the Rise of Homelessness in Los Angeles in the 1980s', in Scott \& Soja, eds., The City: Los Angeles and Urban Theory at the End of the Century, University of California Press, London. 